\title{
INFLUENCE OF GUTTA-PERCHA POINTS ON THE FILLING OF SIMULATED LATERAL CANALS
}

\author{
INFLUÊNCIA DOS CONES DE GUTA-PERCHA NA OBTURAÇÃO \\ DE CANAIS LATERAIS ARTIFICIAIS
}

Juliana Machado BARROSO ${ }^{1}$, Laise Daniela CARRASCO ${ }^{1}$, Alexandre CAPELLI',
Danilo Mathias Zanello GUERISOLI ${ }^{2}$, Paulo César SAQUY ${ }^{3}$, Jesus Djalma PÉCORA

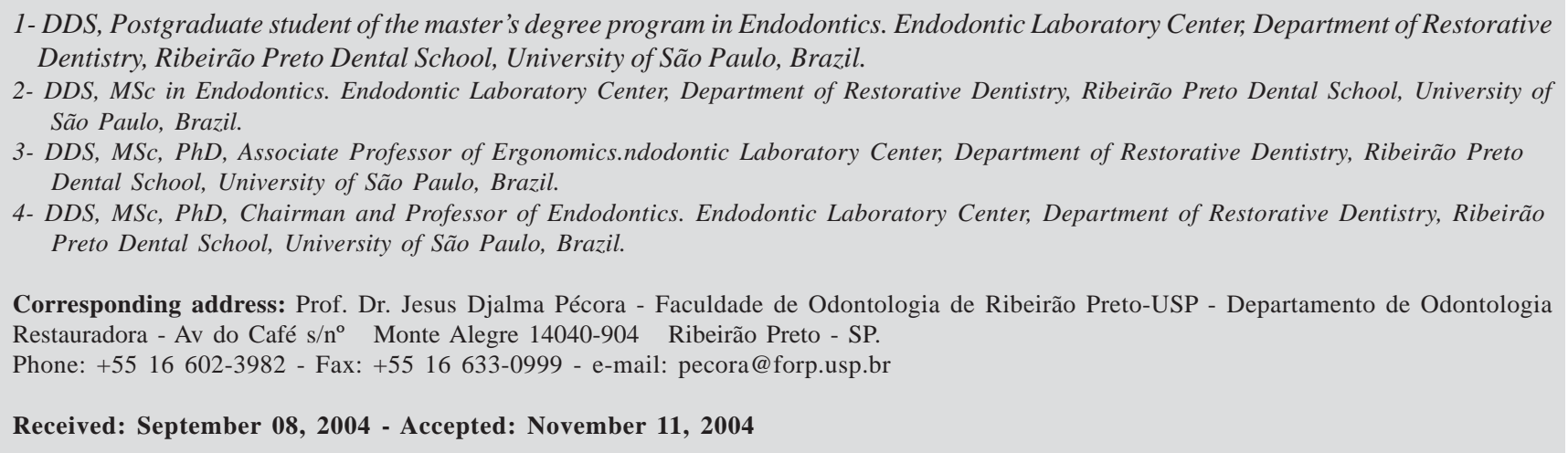

\begin{abstract}
The he aim of this study was to investigate, in vitro, the percentage of filling of simulated lateral canals in teeth obturated with TP medium and standardized gutta-percha points. Twenty human mandibular canines were prepared with LA Axxess (SybronEndo) and $\mathrm{K}^{3}$ Endo rotary system (SybronEndo) up to a \#50 file, according to the Free Tip Preparation Technique. During instrumentation, the root canals were alternately irrigated with $1 \%$ sodium hypochlorite and 17\% EDTA. Six artificial lateral canals were prepared at the apical third of each tooth. Then, the teeth were assigned to two groups $(n=10)$ : Group 1 - filled with TP medium master gutta-percha points (Dentsply, Mailleffer); Group 2 - filled with standardized master gutta-percha points (Dentsply, Mailleffer). Root canal filling was complemented with AH Plus sealer (Dentsply, Mailleffer) and accessory gutta-percha points (Dentsply, Mailleffer), according to the classic technique. The teeth were radiographed and the images obtained were digitized. Linear measurements of the percentage of filling of the artificial lateral canals in each group were accomplished on the Image Tool 2.02 software. Statistical analysis of the data using Mann-Whitney U non-parametric test evidenced significant difference $(\mathrm{p}<0.01)$ between the experimental groups. The group obturated with TP medium points yielded higher percentage of filling of the lateral canals. It may be concluded that the use of master gutta-percha points with larger taper resulted in better filling of the simulated lateral canals, as compared to the use of standardized master gutta-percha points.

Uniterms: Lateral canals; Gutta-percha; Root canal filling.
\end{abstract}

\begin{abstract}
RESUMO
Q

objetivo deste estudo foi avaliar in vitro o percentual de preenchimento de canais laterais artificiais em dentes obturados com cones de guta-percha TP medium e estandardizados. Vinte caninos inferiores humanos foram preparados com os instrumentos LAAxxess (SybronEndo) e o sistema rotatório $\mathrm{K}^{3}$ Endo (SybronEndo) até a lima \#50, de acordo com a técnica Free Tip Preparation. Durante a instrumentação, os canais radiculares foram alternadamente irrigados com solução de hipoclorito de sódio a 1\% e EDTA a 17\%. Seis canais laterais artificiais foram confeccionados no terço apical de cada dente. Os dentes foram então divididos em dois grupos ( $\mathrm{n}=10)$ : Grupo 1 - obturados com cones de guta-percha principais TP médium (Dentsply, Mailleffer), Grupo 2 - obturados com cones de guta-percha principais estandardizados (Dentsply, Mailleffer). A obturação do canal radicular foi complementada com o cimento obturador AH Plus (Dentsply, Mailleffer) e cones de guta-percha acessórios (Dentsply, Mailleffer), de acordo com a técnica clássica. Os dentes foram radiografados e as imagens digitalizadas. Realizou-se a mensuração do percentual de obturação dos canais laterais em cada grupo por meio do software Image Tool 2.02. A análise estatística dos dados por meio do teste não paramétrico Mann-Whitney U evidenciou diferença significante $(p<0.01)$ entre os grupos experimentais. O grupo obturado com cones TP medium promoveu maior percentual de preenchimento dos canais laterais. Pode-se concluir que a utilização de cones de guta-percha principais com maior conicidade resultou obturação mais efetiva dos canais laterais artificiais, quando comparada ao emprego de cones de guta-percha estandardizados.

Unitermos: Canais laterais; Guta-percha; Obturação do canal radicular.
\end{abstract}




\section{INTRODUCTION}

The three-dimensional obturation of the root canals is the final step of an intricate therapeutic chain of procedures that comprises cleansing, disinfection and shaping of the canals $^{9}$. Nevertheless, despite the indisputable advancements of Endodontics, completely sealing the canals after biomechanical preparation remains a critical phase of the endodontic treatment.

The difficulty in adequately obturating the root canal system is ascribed to its anatomical complexity and peculiar morphological configuration, which includes multiple foraminas, apical deltas, accessory and lateral root canals ${ }^{2,5,13}$. Since these components may constitute a pathway for passage of bacteria and products of tissue degradation between the root canal space and the surrounding extradental periodontal environment ${ }^{3}$, the hermetic filling of the entire canal system consists of an essential approach to yield the healing of periapical tissues. Therefore, the overall success of an endodontic treatment is closely related to the filling materials and techniques utilized ${ }^{4,8,16}$.

Unlike the conventional hand files, rotary endodontic instruments are available with several tapers. Based on the conicity of rotary instruments, gutta-percha points of different tapers were also developedm ${ }^{1}$ and the effectiveness of these points as regards the three-dimensional obturation of root canals has yet to be thoroughly investigated. Therefore, the aim of this study was to assess, in vitro, the percentage of filling of simulated lateral canals in teeth obturated with TP medium and standardized master guttapercha points.

\section{MATERIALAND METHODS}

For this study, twenty human mandibular canines were selected and stored in a $0.1 \%$ thymol solution at $9^{\circ} \mathrm{C}$. Before onset of the laboratorial procedures , the teeth were washed in running tap water for 48 hours to eliminate any possible remnants of thymol.

The crowns were sectioned at the cementoenamel junction. Then, the teeth were instrumented using LAAxxess 35/06 burs (SybronEndo, Glendora, CA, USA) for preparation of the cervical and middle thirds of the root canal, and $\mathrm{K}^{3}$ rotary system (SybronEndo, Glendora, CA, USA) in the following sequence: 25/04; 30/04; 25/06; 35/04; 30/06; 40/ 02; 35/06; 45/02 and 50/02. The instrumentation was performed at $1 \mathrm{~mm}$ short of the working length, according to the Free Tip Preparation technique (Pécora, et al., 2002) ${ }^{11}$. The canals were alternately irrigated with $3 \mathrm{~mL}$ of $1 \%$ sodium hypochlorite solution and $2 \mathrm{~mL}$ of $17 \%$ EDTA solution at each change of instrument.

The lateral canals were prepared according to the technique proposed by Pécora, et al. ${ }^{11}$ (2002), with modifications. A \#10 K-file (Dentsply, Mailleffer, De Trey $\mathrm{GmbH}$, Konstanz, Germany) had half of its active point removed and the remaining part of the file was ground with a diamond bur up to a diameter of $150 \mathrm{~mm}$ throughout its extension, as measured by a digital caliper (Tesa Switzerland, Suíça). The ground file was adapted to a lowspeed handpiece and utilized as a bur. Six artificial lateral canals were prepared at the apical third of each root, being three of them located at the mesial surface and three at the distal surface. The distance between the canals was $2 \mathrm{~mm}$, starting from the apical foramen, as schematically illustrated in Figure 1.

The main root canal was then filled with 17\% EDTA solution for 5 minutes and a final irrigation was performed with $3 \mathrm{~mL}$ of $1 \%$ sodium hypochlorite solution. Thereafter, the teeth were immersed in 1\% sodium hypochlorite solution and submitted to vacuum for 5 minutes to assure patency of the lateral canals. Next, the teeth were washed in running tap water and their external surface was dried with absorbent paper. Final irrigation was performed with $2 \mathrm{~mL}$ of distilled water, which revealed complete patency of the lateral canals.

The teeth were randomly assigned to two groups of 10 specimens each. The specimens in Group 1 were obturated with TP medium master gutta-percha points (Dentsply, Mailleffer, De Trey GmbH, Konstanz, Germany), which were previously calibrated in a calibrating ruler (Dentsply, Mailleffer, De Trey GmbH, Konstanz, Germany) to obtain a diameter corresponding to that of a size \#50 gutta-percha point. The specimens in Group 2 were obturated with size \#50 standardized master gutta-percha points (Dentsply, Mailleffer, De Trey GmbH, Konstanz, Germany). In both groups, the root canals were filled with AH Plus cement (Dentsply, Mailleffer, De Trey GmbH, Konstanz, Germany) using the classic technique. First, the sealer was handled and manipulated following the manufacturer's instructions and inserted into the canal with a K-file. Then the master gutta-percha cone was coated with the sealer throughout its extension, including the apical portion, and inserted in a single movement. Canal filling was complemented with the

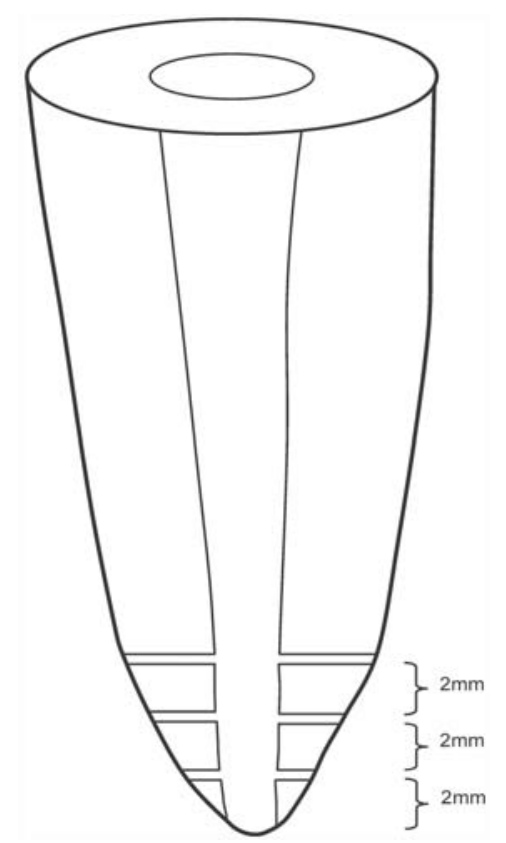

FIGURE 1- Preparation of the artificial lateral canals 
insertion of accessory gutta-percha points (Dentsply, Mailleffer, De Trey GmbH, Konstanz, Germany), using the active lateral condensation technique.

Afterwards, rectangular lead blades with the approximate length of the root and $1.5 \mathrm{~mm}$ of width were positioned along the root at both mesial and distal sides and fixed on the external opening of the lateral canals. This approach aimed to accurately delimitate the length of the simulated lateral canals and therefore assure that the full extension of filling of the artificial canals would be precisely determined radiographically. The teeth were then radiographed at 70Kvp and 10mA (Dabi-Atlante, Ribeirão Preto, São Paulo, Brasil), with a focus-film distance of $16 \mathrm{~cm}$. The radiographs (KodakSão José dos Campos, São Paulo, Brasil) were processed according to a standardized protocol and the images obtained were digitized in a scanner (Genius Color Page HR6, KYE, Systems Corporation, Brasil).

Based on the digitized images, the total length of each of the six simulated lateral canals in each tooth of both groups was measured. Likewise, the linear extension of the obturation in each canal was determined. These measurements were obtained using Image Tool UTHSCSA Image Tool Version 2.02 software. From the measurements recorded, the percentage of filling material present in the artificial lateral canals was calculated. Data were submitted to statistical analysis using Mann-Whitney U nonparametric test.

\section{RESULTS}

The Mann-Whitney U non-parametric test evidenced that, as regards the filling of the simulated lateral canals, the group obturated with TP medium gutta-percha points (' $\mathrm{x}$ $96.17 \pm 13.50$ ) yielded better results than the group filled with standardized points (' $x$ 70.07 \pm 37.13 ). This difference was statistically significant at the 0.01 level.

\section{DISCUSSION}

The success of endodontic therapy after obturation of the lateral canals has been investigated using different filling materials and techniques proposed to obtain a more accurate filling of such canals ${ }^{1,2,14}$.

Experimental models that allow assessing the filling of root canals according to a standardized and controlled protocol are not always viable to be conducted in vivo. Therefore, in an attempt to overcome the shortcomings of in vivo studies, Reader, et al. ${ }^{13}$ (1993) and Dulac, et al. ${ }^{2}$ (1999) have suggested to compare the ability of different obturation techniques for filling of lateral canals by using root canals artificially prepared in acrylic blocks. Nevertheless, the major limitation of this methodology consists in stating a reliable comparison between resin and dentin. The current study was conducted on, human teeth with simulated lateral canals, as proposed by Goldberg, et al. ${ }^{5}$ (2002) and Pécora, et al. ${ }^{12}$ (2002), aiming at developing an experimental model as close as possible to the ideal clinical conditions ${ }^{7}$.

The diameter of the lateral canals artificially prepared in this study corresponded to $150 \mathrm{~mm}$, which is in agreement with the diameter of lateral canals reported in former studies ${ }^{12,15}$. Nevertheless, the methodology proposed by Pécora, et al. ${ }^{12}$ (2002) for preparation of artificial lateral canals was modified in this study. To simulate lateral root canals of similar diameter throughout their extension, the active point of the K-file used for preparation of the canals was trimmed until a diameter of $150 \mathrm{~mm}$ was obtained throughout its extension.

For both experimental groups, the cold lateral condensation technique of gutta-percha was used, which is the obturation technique most employed in Endodontics ${ }^{4,10,16}$.

In the current work, it was possible to evidence that the taper of the gutta-percha points utilized influenced the filling of the lateral canals. The group obturated with TP medium master gutta-percha points yielded better results than the group obturated with standardized master gutta-percha points. This fact may possibly be attributed to the larger taper of the TP medium points, which, when introduced into the root canal, act similarly to a syringe piston, pushing the sealer into the lateral canals.

The standardized gutta-percha points have a 0.2 taper. It has been demonstrated that the obturation of root canals prepared with Ni-Ti instruments (0.2; $0.4 ; 0.6$ taper) using standardized gutta-percha points with the lateral condensation technique, required the use of a higher number of accessory gutta-percha points to provide an adequate sealing between the main gutta-percha point and the root canal walls ${ }^{6}$. Accordingly, the outcomes of the present study showed that root canal filling with TP medium gutta-percha points demanded a lower number of accessory points and provided a more accurate obturation, as compared to the use of standardized points.

It is important to highlight that this study utilized teeth with straight roots and single canals, whereas most posterior teeth have a more complex anatomic configuration with a number of isthmus, curvatures and foraminas. Even so, we expect that the findings of this study may widen the scopes on the filling of lateral canals and prompt the development of further researches that investigate whether, in multi-rooted teeth, gutta-percha points with larger tapers would also provide better sealing of lateral canals than standardized points.

\section{CONCLUSION}

Based on the methodology employed and results obtained, it may be concluded that the use of master guttapercha points with larger taper resulted in better filling of the simulated lateral canals, as compared to the use of standardized master gutta-percha points. 


\section{REFERENCES}

1- Bal AS, Hicks Ml, Barnett F. Comparison of laterally condensed .06 and .02 tapered gutta-percha and sealer in vitro. J Endod. 2001 Dec;27(12):786-8.

2- Dulac KA, Nielsen CJ, Tomazic TJ, Ferrillo PJ Jr, Hatton JF. Comparison of the obturation of lateral canals by six techniques. J Endod. 1999 May;25(5):376-80.

3- De Deus Q D. Frequency, location, and direction of the lateral, secondary, and accessory canals. J Endod. 1975 Nov;1(11):361-6.

4- Facer SR, Walton RE. Intracanal distribution patterns of sealers after lateral condensation. J Endod. 2003 Dec;29(12):832-4.

5- Goldberg F, Artaza LP, Silvio Ade. Effectiveness of different obturation techniques in the filling of simulated lateral canals. J Endod. 2001 May;27(5):362-4.

6- Hembrough MW, Steiman HR, Belanger K K. Lateral condensation in canals prepared with nickel titanium rotary instruments: an evaluation of the use of three different master cones. J Endod. 2002 Jul;28(7):516-9.

7- Holland R, Murata SS. Obturação de canais radiculares com cimento à base de hidróxido de cálcio. Rev Assoc Paul Cir Dent. 1995 May/ Jun;49:221-4

8- Imai Y, Komabayashi T. Properties of a new injectable type of root canal filling resin with adhesiveness to dentin. J Endod. 2003 Jan;29(1):20-3.

9- Ingle JI, Bakland LK, Glick DH, Hoskinson, AE. Modern endodontic therapy. Philadelphia: Endodontics; 2002.

10- Jacobson Hl, Xia T, Baumgartner JC, Marshall JG, Beeler WJ. Microbial leakage evaluation of the continuous wave of condensation. J Endod. 2002 Apr;28(4):269-71.

11- Pécora JD, Capelli A, Seixas FH, Marchesan MA, Guerisoli DMZ. Biomecânica Rotatória: Realidade ou Futuro? Rev Assoc Paul de Cir Dent. 2002 Jun;58 (Supl):4-6.

12- Pécora JD, Ribeiro RG, Guerisoli DMZ, Barbizan JVB, Marchesan MA. Influence of the spatulation of two zinc oxide-eugenol-based sealers on the obturation of lateral canals. Pesqui Odontol Bras. 2002 Mar/Apr;16(2):127-30

13- Reader CM, Himel VT, Germain LP, Hoen MM. Effect of three obturation techniques on the filling of lateral canals and the main canal. J Endod. 1993 Ago;19 (8):404- 8.

14- Reeh ES, Combe EC. New core and sealer materials for root canal obturation and retrofilling. J Endod. 2002 Jul;28(7):520-3.

15- Vertucci FJ, Anthony Rl. A scanning electron microscopic investigation of accessory foramina in the furcation and pulp chamber floor of molar teeth. Oral Surg Oral Med Oral Pathol. 1986 Sept;62(3):319-26.

16- Vizgirda PJ, Liewehr FR, Patton WR, Mcpherson JC, Buxton TB. A comparison of laterally condensed gutta-percha, thermoplasticized gutta-percha, and mineral trioxide aggregate as root canal filling materials. J Endod. 2004 Feb;30(2):103-6. 